Cite as: Grohmann, C.H., Riccomini, C., Alves, F.M., 2007. SRTMbased morphotectonic analysis of the Poços de Caldas Alkaline Massif, southeastern Brazil. Computers \& Geosciences, 33:10-19.

DOI:10.1016/j.cageo.2006.05.002

\title{
SRTM-based morphotectonic analysis of the Poços de Caldas Alkaline Massif, southeastern Brazil
}

Carlos Henrique Grohmann ${ }^{\mathrm{a}^{*}}$, Claudio Riccomini ${ }^{\mathrm{b}}$, Fernando Machado Alves ${ }^{\mathrm{a}}$

* - corresponding author

a - Programa de Pós-Graduação em Geoquímica e Geotectônica

Instituto de Geociências - Universidade de São Paulo, Brasil.

Rua do Lago, 562, 05508-080, São Paulo, SP, Brasil.

Phone $+55-11-30914216$

Fax +55-11-30914258

E-mail address: guano@usp.br, carlos.grohmann@gmail.com

E-mail address: fernando.alves@erm.com

b-Departamento de Geologia Sedimentar e Ambiental

Instituto de Geociências - Universidade de São Paulo, Brasil.

Rua do Lago, 562, 05508-080, São Paulo, SP, Brasil.

Phone $+55-11-3091$

Fax +55-11-3091

E-mail address: riccomin@usp.br

\begin{abstract}
An evaluation of SRTM 03" data applicability in geomorphology and morphotectonics analysis is proposed, considering the morphometric parameters slope, aspect, surface roughness and isobase surface. The study area, in southeastern Brazil, comprises the Poços de Caldas Alkaline Massif, a 33km-diameter Late Cretaceous collapsed volcanic caldera. Morphometric indices evaluated showed the correlation of landscape within the massif with NE-SW and NW-SE structures, as well as landforms related with recent tectonic influence. DEM-derived drainage presented satisfactory results when compared to a 1:50 000 topographic map. SRTM 03" proved to be a good resource for geomorphological analysis, up to the semi-detail scale.
\end{abstract}

Keywords: SRTM; DEM; Morphometric analysis; Geomorphology; Poc-os de caldas; Alkaline massif 


\section{Introduction}

Morphometric analysis, or geomorphometry, is the practice of terrain modeling and ground-surface quantification, through applications of Earth sciences, mathematics, engineering and computer science (Pike 2002). Geographic Information Systems (GIS) and Digital Elevation Models (DEMs) allow speed, precision and reproducibility to calculation of morphometric parameters.

The release of SRTM DEM data (Farr and Kobrick 2000; van Zyl 2001; Rabus et al., 2003) brought the possibility of regional geomorphological analysis in a fast and inexpensive way.

In this work, we considered the morphometric parameters slope, aspect, surface roughness and isobase surface to present an evaluation of SRTM 03" data applicability in geomorphology and morphotectonics. The study area, locate in southeastern Brazil, comprises the Poços de Caldas Alkaline Massif, a 33km-diameter Late Cretaceous collapsed volcanic caldera.

\section{Geological and geomorphological context}

The Cabo Frio Magmatic Lineament, as defined by Almeida (1991), is a WNW-ESE structural feature, $60 \mathrm{~km}$ wide by $1150 \mathrm{~km}$ long, developed from Jaboticabal (Northern São Paulo State) eastwards, up to the Almirante Saldanha Bank, region of the boundary between continental and oceanic crusts.

Located in the central-western portion of the Cabo Frio Magmatic Lineament, the Poços de Caldas Alkaline Massif (Figs. 1, 2) is the largest alkaline complex in Brazil with about $800 \mathrm{~km}^{2}$, composed mainly of nepheline syenites, phonolites, ankaratrites and volcanoclastic rocks (phonolitic tuffs and lapilli-tuffs, volcanic agglomerates and breccias); diabases, carbonatites and ultramafic ultrapotassic biotite lamprophyre dikes occur as subordinated rock types (Ulbrich and Gomes 1981, Schorscher and Shea 1992, Alves 2003). Shea (1992) obtained an Ar-Ar age of $78 \pm 3$ Ma for the central nepheline syenite body of the caldera, representing one of the earlier stages of its evolution, and an age of $76 \pm 2 \mathrm{Ma}$ for a lamprophyre dike related to the final stage of volcanic activity.

The alkaline massif main morphology is a semi-circular plateau with average altitude of $1300 \mathrm{~m}$ rising up to $400 \mathrm{~m}$ above surrounding flatlands (Poços de Caldas Plateau, Fig. 2), with elevations up to $1500-1600 \mathrm{~m}$ in its borders. Original vegetation coverage consisted of cerrado (savanna) and now most of the area is covered by pasture (RADAMBRASIL 1983).

This plateau is a remnant of the South American Planation Surface (King 1956, 1967) and resulted from differential erosion of basement rocks and volcanic ring dikes around the massif at the Late Cretaceous-Paleogene transition. Landforms within the massif are closely linked with contrasts in lithology (Holmes et al., 1992) and with Pleistocenic and Holocenic tectonic structures (Alves 2004). Contrast between tectonic and lithologic influence on geomorphology favors morphotectonic analysis. 


\section{Methods}

Analysis were carried out with free software GRASS-GIS (Neteler and Mitasova 2004, GRASS Development Team 2005) as proposed by Grohmann (2004). Original SRTM data were imported into GRASS, reprojected to UTM coordinate system and resampled by nearest neighbors to a spatial resolution of 50m, in order to work at a 1:50 000 scale. In the original data only a small void was present, and was filled by interpolation with regularized splines with tension (RST - Mitasova and Hofierta 1993, Mitasova and Mitas 1993).

Slope and aspect were calculated with a 3x3 neighborhood operator (Horn 1981). Aspect was converted from its original output (i.e., counterclockwise from east) to conventional orientation (clockwise from north) and classified into eight categories, each corresponding to a $45^{\circ}$ interval.

Day (1979) describes surface roughness as the expression of non-systematic variability of the topographic surface, and used the dispersion of vector normals to surface plans as a roughness indicator to discriminate tropical karst stiles. Hobson (1972), describes it as the ratio between surface (real) area and flat (plan) area of square cells; in this approach, flat surfaces would present values close to 1, whilst in irregular ones the ratio shows a curvilinear relationship which asymptotically approaches infinity as the real areas increases.

Ferrari et al. (1998) argue that surfaces with distinct characteristics can present the same roughness value, due the existence of interactions between the number and magnitude of terrain irregularities. Grohmann (2004), considers this method useful for morphological characterization since it is mainly related with the shape of landforms and not its elevation; thus, tectonically tilted areas have their expression shown, while it could be masked in a hypsometric map, as consequence of altimetric variations.

In this work, surface roughness was considered as the ratio between surface and plan area of $1 \mathrm{x} 1 \mathrm{~km}$ cells. Surface area of the $1 \mathrm{~km}$ cells was achieved by summing up the real area of individual cells (50x50m, Fig. 6b) within a $1 \times 1 \mathrm{~km}$ window.

SRTM data can be biased by canopy variations; in areas of dense forest coverage such effect can account for increasing overall DEM height and act as a smooth blanket over terrain, hiding minor details (Valeriano et al. 2006). In the study area, original vegetation was widely removed and replaced by pasture; in its original form it consists of cerrado, savanna-like grassland scattered with shrubs and isolated trees (Radambrasil 1983).

Prior to drainage extraction, the DEM was smoothed with a $7 \mathrm{x} 7$ filter that fits quadratic surfaces to elevation values (r.param.scale command, Wood 1996a,b), in order to prevent creation of artifacts (O'Callaghan and Mark 1984, Garbrecht and Martz 1999) and to minimize both the effects of noise that SRTM data presents in flat areas (Guth 2006, Huisenga 2005) and possible canopy variations.

Drainages were calculated using the $\mathrm{A}^{\mathrm{T}}$ least-cost search algorithm (r.watershed command, Ehlschlaeger 1989), with a threshold value of 50 cells as minimum watershed size (Fig. 5); DEM-derived drainage can be compared against drainage from a 1:50 000 topographic map in Figure 6. Raster streams were converted to vectors and manually classified according to Strahler's (1952) drainage order scheme. 
The isobase method (Filosofov 1960, Golts and Rosenthal 1993), concerns about relations between stream channel order and topography. The stream order refers to the relative position of stream segments in a drainage basin network; within such basin, streams of similar orders relate to similar geological events and are of similar geological age (Golts and Rosenthal 1993).

According to Filosofov (1960), isobase is a line which delineates an erosional surface; the isobase surface is formed by connecting stream profiles of similar order and disregarding topography above isobase surface (Fig. 7).

Isobase lines draw erosional surfaces, hence isobase surfaces are related to tectonicerosional events, mainly the most recent ones. Abrupt deviations in isobase lines directions may be reflect of tectonic dislocations or severe lithological changes (Golts and Rosenthal 1993).

The isobase map can be seen as a "simplified" version of the original topographic surface, from which was removed the "noise" of the $1^{\text {st }}$-order streams erosion. The main goal of this method is to be able to identify areas with possible tectonic influence even within lithological uniform domains, what cannot be achieved with "base-level" maps, usually constructed from elevations of thalwegs in a given area, or with swath profiles (Baulig 1926, Tricart and Cailleux 1957) were intersections of contours with equally spaced profile lines are marked within a swath, or band; this kind of profile is useful to provide a broader view of altimetric behavior and help to determine inclination of large topographic features in planaltic regions (Meis et al., 1982).

The isobase map (Fig. 8) was made by RST interpolation of altitude values from intersections of contours with $2^{\text {nd }}$ and $3^{\text {rd }}$-order stream channels .

\section{Discussion}

The Poços de Caldas Alkaline Massif stands as a high plateau in a strongly eroded area, and preserves, in its ring dikes, the remnants of the South American Planation Surface, developed at the Late Cretaceous-Paleogene transition.

Slopes within the massif are small, generally lower than $10^{\circ}$ (Poços de Caldas Plateau); higher values, up to $40^{\circ}$, occur mainly in the massif's borders (Fig. 3). Localized areas with high slope values occur within the Plateau, generally aligned NE-SW. The aspect map shows slopes facing mostly NW and SE within the Plateau, controlled by NE-SW lineaments; the volcanic edifice exhibits a radial pattern of aspect distribution.

In the surface roughness map (Fig. 4a) is possible to see some very flat areas, with values close to 1, roughly aligned NE-SW (northern Plateau) and NW-SE (southern Plateau). The expression of the massif borders is marked by the higher values, ranging from 1.07 up to 1.15 .

The isobase map (Fig. 8) not only gives a good delimitation of the massif, with higher values, but also presents some typical characteristics of areas that went trough tectonic activities, such as approach, separation and sudden inflection of isobase lines (Golts and Rosenthal 1993). Isobase lines within the plateau show trends in NE-SW and NW-SE directions, both in areas were lines are close to each other as were they are separated.

There is a partial coincidence of a lithologic change in the northeastern portion of the massif and a strong NE-SW isobase anomaly, which turns abruptly to NW-SE in the 
central area of the plateau, without any associated variation in lithology. This large anomaly is related with a NE-SW fault that cuts throughout the entire massif (Fig. 2), identified by Almeida Filho and Paradella (1977).

Geomorphological settings related to tectonic and lithologic controls can be better seen when the geological map is draped over a 3D model of isobase surface (Fig. 9). Sandstones in the western border of the massif are in a depressed region, while the strong NE-SW isobase anomaly roughly follows the contact of the central nepheline syenite body and turns to a NW-SE direction in a lithological homogene area.

Morphological profiles across the massif in the N-S (Fig. 10a) and SW-NE (Fig. 10b) directions shows the relations between topography and isobase. Although the isobase curve does not pass exactly under the valley bottoms, perhaps due the need of fine adjustments to interpolation parameters, it is possible to see areas where the $1^{\text {st }}$-order drainages incision is more prominent, thus more likely to reflect strong differences in weathering resistance of rocks, or recent tectonic activity.

\section{Conclusions}

The contrast between tectonic and lithologic influence on Poços de Caldas Alkaline Massif's geomorphology favors morphotectonic analysis. Regional geomorphological configuration is a remnant of the Late Cretaceous-Paleogene South American Planation Surface, while landscape within the plateau is controlled by structures trending NE-SW and NW-SE. Isobase analysis allowed discrimination of areas where the dominant geomorphic process is related to differential erosion from areas affected by recent tectonics. Drainage extraction from DEM presented satisfactory results when compared to a 1:50 000 topographic map.

SRTM DEM proved to be a good resource for geomorphological analysis at a semidetail scale. Availability of data assures that analysis can be carried out in a fast and inexpensive way, even in areas of poor topographic coverage.

\section{Acknowledgements}

This work was supported by FAPESP grant 04/06260-5 (C.H.G. Doctor's Degree Fellowship) and CNPq grant 303910/1986-0 (C.R.).

The authors are thankfull to all who have contributed to the development of this work, to the anonymous reviewers for their critics and suggestions and to all participants of the Shuttle Radar Topography Mission Data Validation and Applications Workshop, held in the USGS Headquarters (Reston, VA), in June 2005. 


\section{References}

Almeida Filho, R.; Paradella, W.R., 1977. Estudo do Maciço Alcalino de Poços de Caldas através de imagens Landsat com ênfase em mineralizações radioativas. INPE (11/2-TPT/065).

Almeida, F.F.M., 1991. O alinhamento magmático de Cabo Frio. In: Simpósio de Geologia do Sudeste, 2, São Paul. Atas, São Paulo, SBG/SP-RJ, pp. 423-428.

Alves, A.D., 2003. Rochas vulcanoclásticas do Complexo Alcalino de Poços de Caldas - MG/SP. University of São Paulo, Brazil, Institute of Geosciences, M.Sc. Dissertation, $106 \mathrm{p}$.

Alves, F.M., 2004. Tectônica rúptil do Maciço Alcalino de Poços de Caldas no contexto do Alinhamento Magmático de Cabo Frio. University of São Paulo, Brazil, Institute of Geosciences, Undergraduate Monography, 47p.

Baulig, H., 1926. Sur une méthode d'analyse altimétrique appliquée à la Bretagne. Bulletin de l'Association de Geographie Francaise 10,7-9

Day, M.J., 1979. Surface roughness as a discriminator of tropical karst styles. Zeitschrift für Geomorphologie, Suppl., 32:1-8.

Ehlschlaeger, C.R., 1989. Using the $\mathrm{A}^{\mathrm{T}}$ Search Algorithm to Develop Hydrologic Models from Digital Elevation Data. Proceedings of International Geographic Information Systems (IGIS) Symposium '89, Baltimore, pp:275-281.

Farr, T.G., Kobrick, M., 2000. Shuttle Radar Topography Mission produces a wealth of data. Amer. Geophys. Union Eos, 81:583-585.

Ferrari, J.A., Hiruma, S.T., Karmann, I., 1998. Caracterização morfométrica de uma superfície cártsica do Vale do Ribeira, São Paulo (Núcleo Caboclos - PETAR). Revista do Instituto Geológico, 19:9-17.

Filosofov, V.P., 1960. Brief guide to morphometric methods in search of tectonic structures. Saratov, Saratov Univ. Publ. House. [in Russian]

Garbrecht, J., Martz, L.W., 1999. Digital Elevation Model Issues in Water Resources. Modeling. In:1999 ESRI Users Conference Proceedings. Eletronic Document: http://gis.esri.com/library/userconf/proc99/proceed/papers/pap866/p866.htm

Golts, S., Rosenthal, E., 1993. A morphotectonic map of the northern Arava in Israel, derived from isobase lines. Amsterdam: Geomorphology, 7:305-315.

GRASS Development Team, 2005. Geographic Resources Analysis Support System (GRASS), GNU General Public License. Eletronic document, http://grass.itc.it

Grohmann, C.H., 2004. Morphometric analysis in Geographic Information Systems: applications of free software GRASS and R. Computers \& Geosciences, 30:1055-1067. Guth, P.L., 2006. Geomorphometry from SRTM: Comparison to NED. Photogrammetric Engineering and Remote Sensing, 72:269-278.

Hobson, R.D., 1972. Surface roughness in topography: quantitative approach. In: Chorley, R.J. (ed) Spatial analysis in geomorphology. Methuer, London, p.225-245.

Holmes, D.C., Pitty, A.E., Noy, D.J., 1992. Geomorphological and hydrogeological features of the Poços de Caldas analogue study sites. Journal of Geochemical Exploration, 45:215-247.

Horn, B.K.P., 1981. Hill Shading and the Reflectance Map, Proceedings of the IEEE, 69:14-47. 
Huisenga, J., 2005. Impact of SRTM Data on Geospatial Support to US Army Operations. The Shuttle Radar Topography Mission Data Validation and Applications Workshop, Reston VA, Abstracts:43.

King, L.C., 1956. Geomorfologia do Brasil Oriental. Revista Brasileira de Geografia, 18:147-266.

King, L.C., 1967. Morphology of the Earth. (2nd Ed.) Oliver \& Boyd, Edinburgh.

Meis, M.R.M., Miranda, L.H.G., Fernandes, N.F., 1982. Desnivelamentos de altitude como parâmetros para a compartimentação de relevo: bacia do médio-baixo Paraíba do Sul. In:Congresso Brasileiro de Geologia, XXXII, Salvador, v.4, pp.1489-1503.

Mitasova, H., Hofierta, J., 1993. Interpolation by regularized spline with tension:II. Application to terrain modeling and surface geometry analysis. Mathematical Geology. 25:657-669.

Mitasova, H., Mitas, L., 1993. Interpolation by regularized spline with tension:I. Theory and implementation. Mathematical Geology. 25:641-655.

Neteler, M., Mitasova, H., 2004. Open Source GIS: A GRASS GIS Approach. Second Edition. Boston, Kluwer Academic Publishers, 424p.

O'Callaghan, J.F., Mark, D.M., 1984. The Extraction of Drainage Networks from Digital Elevation Data. Computer Vision, Graphics, and Image Processing, 28:323-344.

Pike, R.J., 2002. A Bibliography of Terrain Modeling (Geomorphometry), the Quantitative Representation of Topography-Supplement 4.0. U.S. Geological Survey Open-File Report 02-465.

Rabus, B., Eineder, M., Roth, R., Bamler, R., 2003. The shuttle radar topography mission--a new class of digital elevation models acquired by spaceborne radar. ISPRS Journal of Photogrammetry and Remote Sensing, 57:241-262.

Radambrasil. 1983. Levantamento de Recursos Naturais. Rio de Janeiro/Vitória: geologia, geomorfologia, pedologia, vegetação e uso potencial da terra. Rio de Janeiro, Ministério de Minas e Energia, folhas SF.23/24p.

Riccomini, C., Velázquez, V.F., Gomes, C.B., 2005. Tectonic controls of the Mesozoic and Cenozoic alkaline magmatism in central-southeastern Brazilian Platform. In: Gomes, C.B. \& Comin-Chiaramonti, P. (eds) Mesozoic to Cenozoic alkaline magmatism in central-southeastern Brazilian Platform, p.1-26. (in press)

Ruberti, E., Gomes, C.B., Melcher, G.C., Ulbrich, H.H.G.J., Ulbrich, M.N.C., 2000. The Jacupiranga Carbonatite Complex (Part I) and the Poços de Caldas Massif (Part II) - São Paulo and Minas Gerais States, Eastern Brazil. In: International Geological Congress, 31, Rio de Janeiro, Brazil, August 6-17, 2000. Post-Congress Field Trip Aft 08 Guide. Rio de Janeiro, 44pp.

Schorscher, H.D., Shea, M.E., 1992. The regional geology of the Poços de Caldas alkaline complex: mineralogy and geochemistry of selected nepheline syenites and phonolites. Journal of Geochemical Exploration, 45:25-51.

Shea, M.E., 1992. Isotopic geochemical characterization of selected nepheline syenites and phonolites from Poços de Caldas alkaline complex, Minas Gerais, Brazil. Journal of Geochemical Exploration 45:173-214.

Strahler, A.N., 1952. Hypsometric (area-altitude) analysis of erosional topography. Colorado: Bulletin of the Geological Society of America, 63:1117-1142. 
Tricart, J., Cailleux, A., 1957. Cours de Geomorphologie I: Geomorphologie Structurale. C.D.U. Paris. 252pp.

Ulbrich, H.H.G.J., Gomes, C.B., 1981. Alkaline rocks from continental Brazil. Earth Science Reviews, 17:135-154.

Valeriano, M.M., Kuplich, T.M., Storino, M., Amaral, B.D., Mendes Jr., J.N., Lima, D.J., 2006. Modeling small watersheds in Brazilian Amazonia with shuttle radar topographic mission-90m data. Computers \& Geosciences, in press.

van Zyl, J.J., 2001. The Shuttle Radar Topography Mission (SRTM): a breakthrough in remote sensing of topography. Acta Astronautica, 48:559-565.

Wood, J., 1996a. Scale-based characterization of Digital Elevation Models. In: Parker D. (ed.) Innovations in GIS 3, Ch. 13, London: Taylor and Francis.

Wood, J., 1996b. The Geomorphological characterization of Digital Elevation Models. University of Leicester, U.K., Department of Geography, PhD Thesis, 185p. 


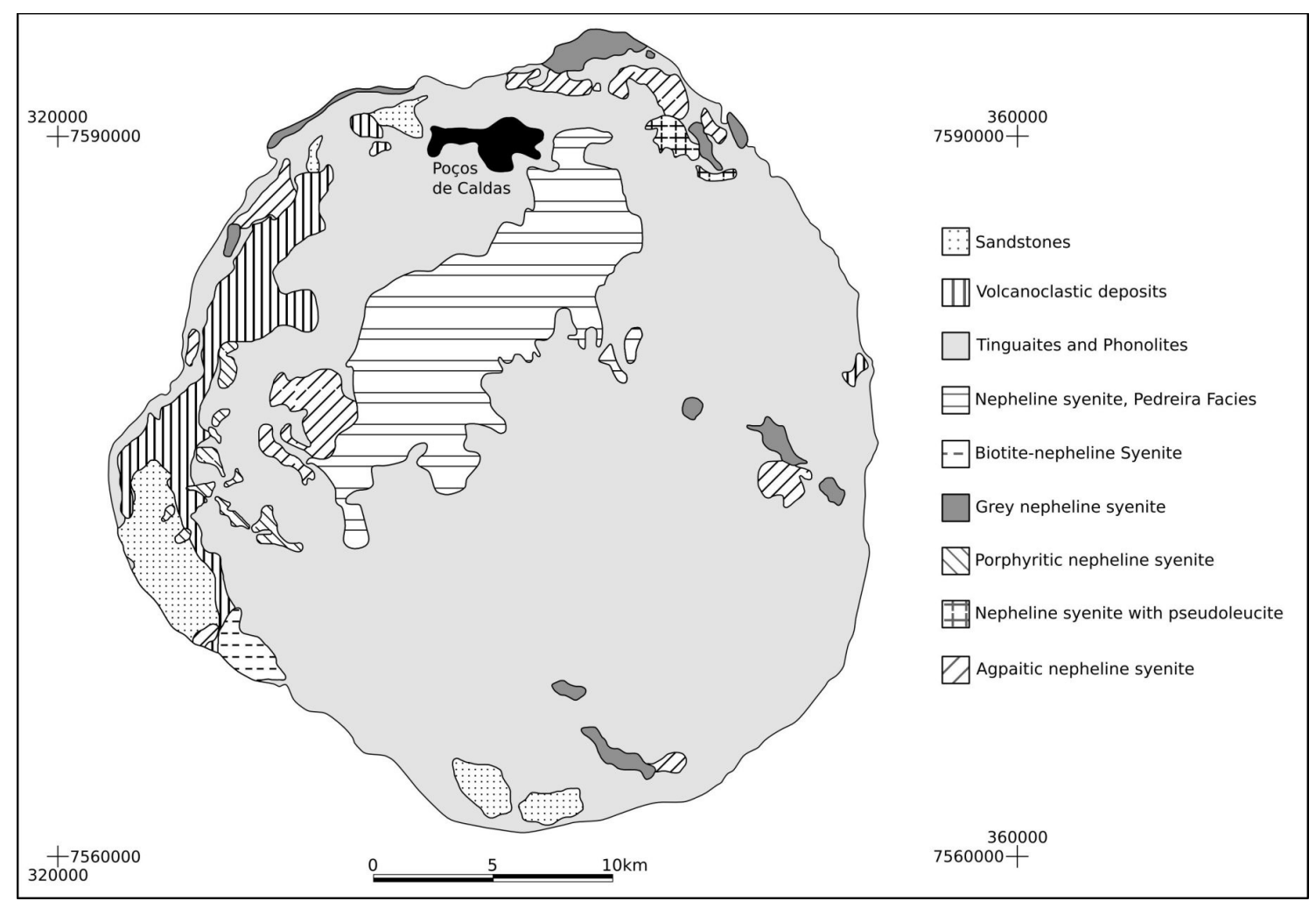

Figure 1. Simplified geological map of the Poços de Caldas Alkaline Massif. After Ruberti et al. 2000. UTM coordinate system, Zone 23, southern hemisphere. 


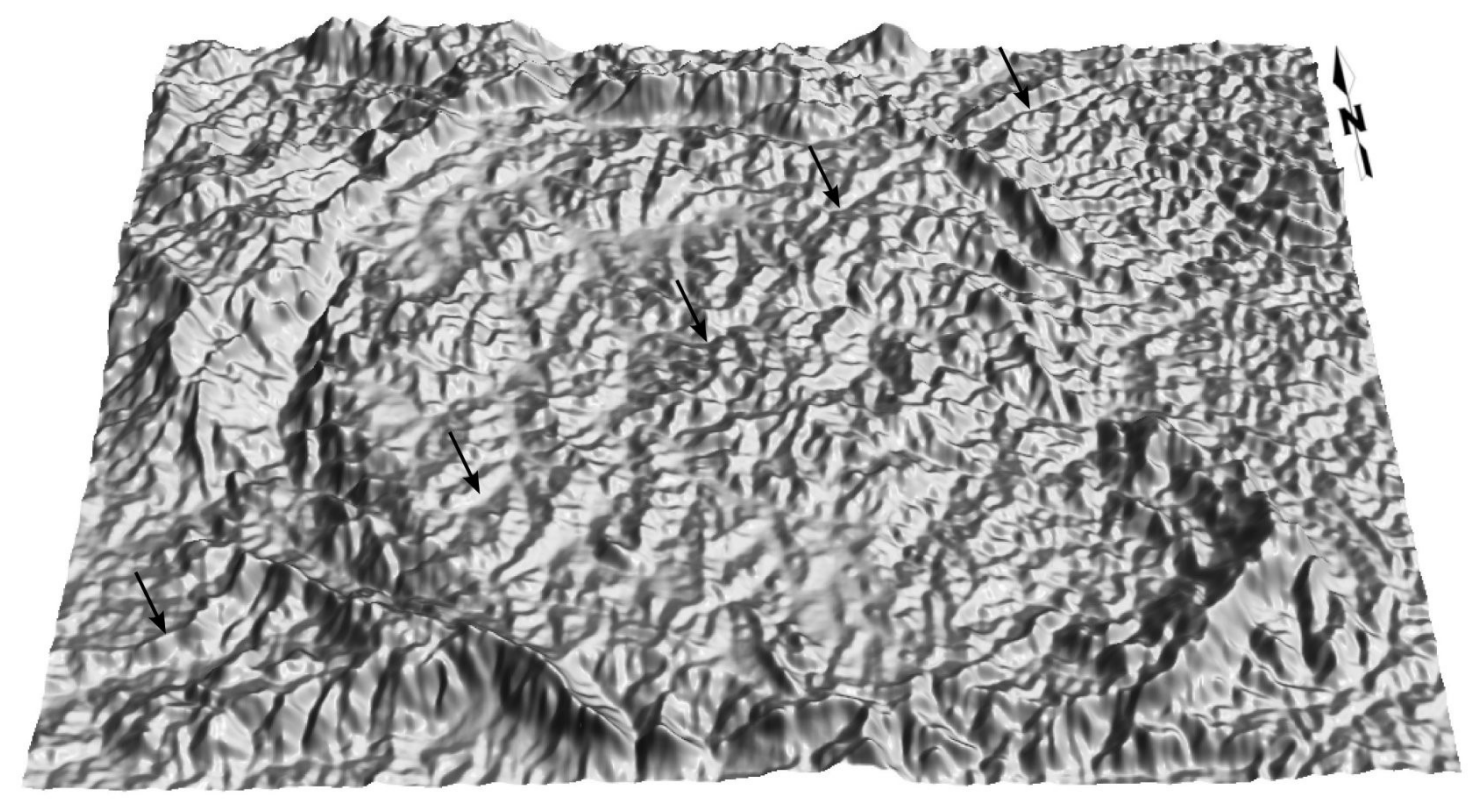

Figure 2. SRTM DEM 3D Perspective of the Poços de Caldas Alkaline Massif, view from south to north, vertical exageration of $3.5 x$. 


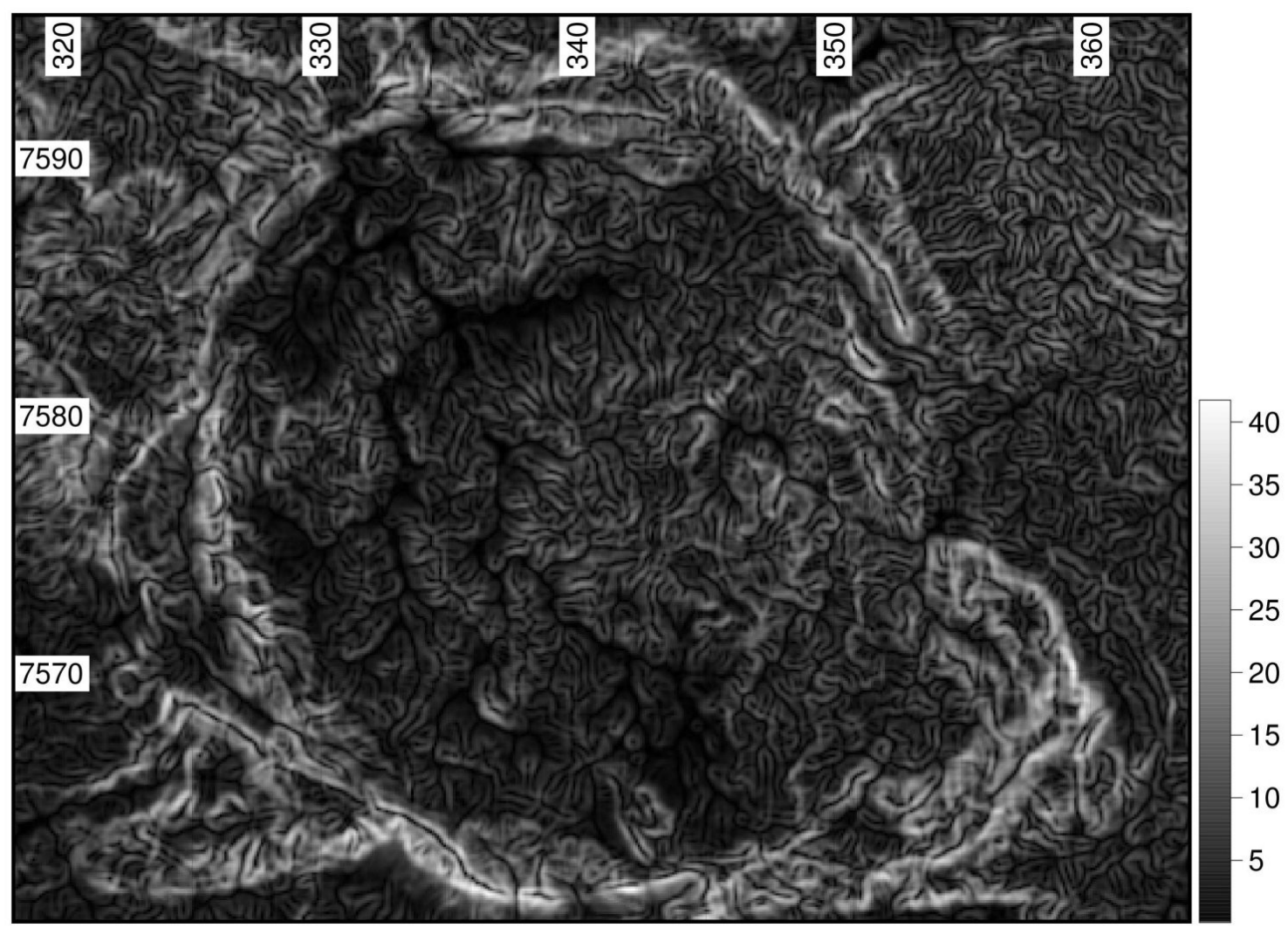

Figure 3. Slope map. Values in degrees. 

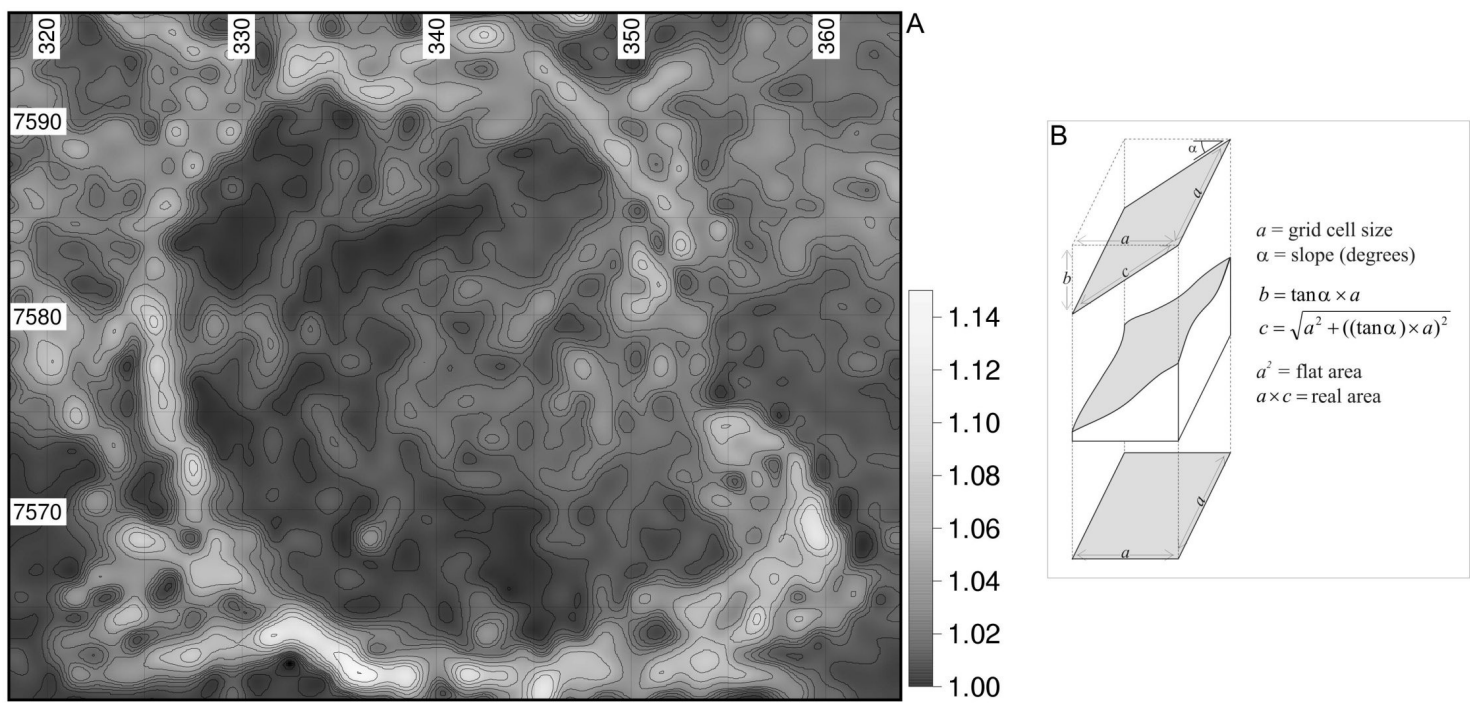

Figure 4. (a) Surface roughness map, for cells with $1 \times 1 \mathrm{~km}$. (b) geometric relations between regular grid and slope. 


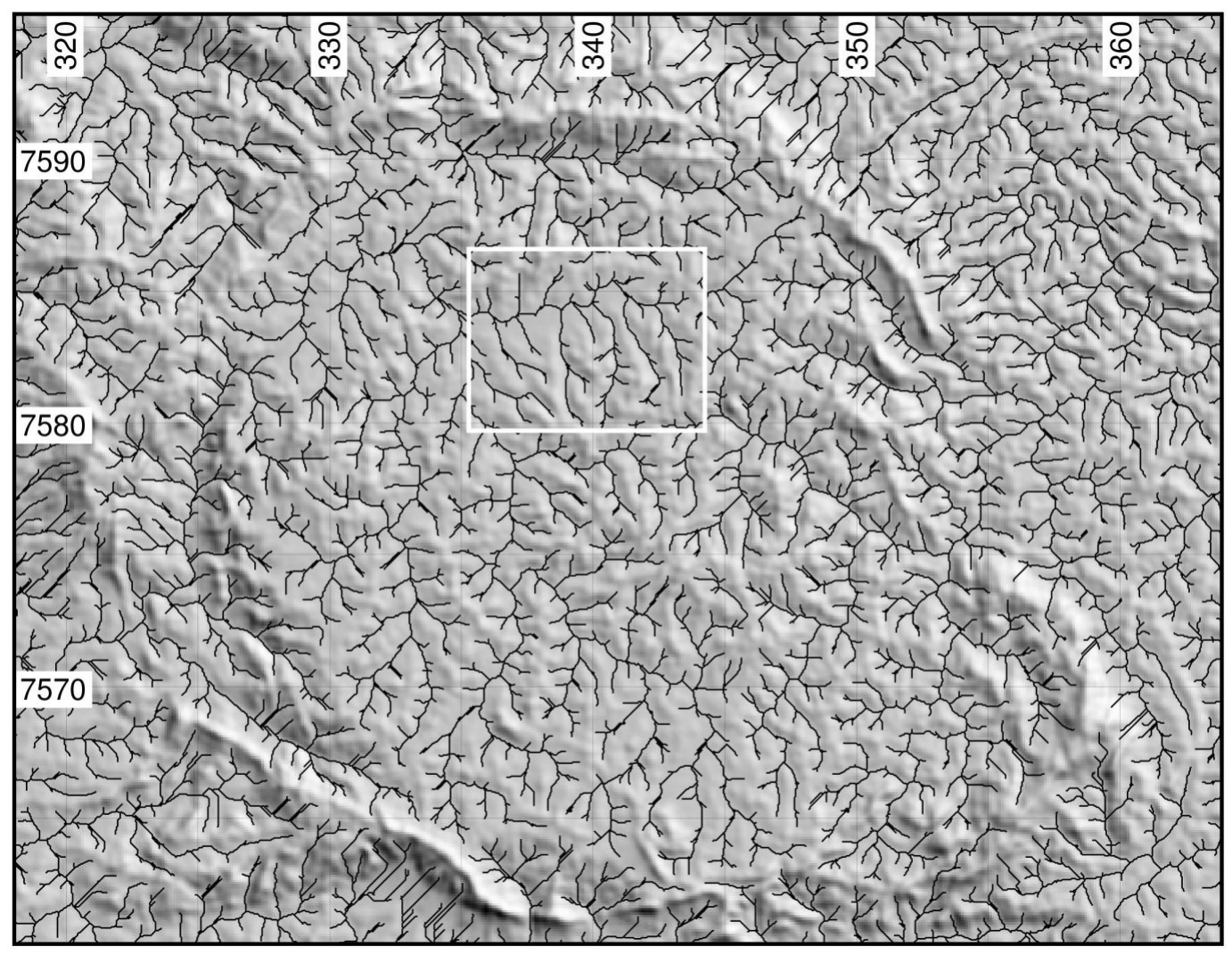

Figure 5. DEM-derived drainages over shaded relief image. White rectangle area is enlarged in Figure 6. 


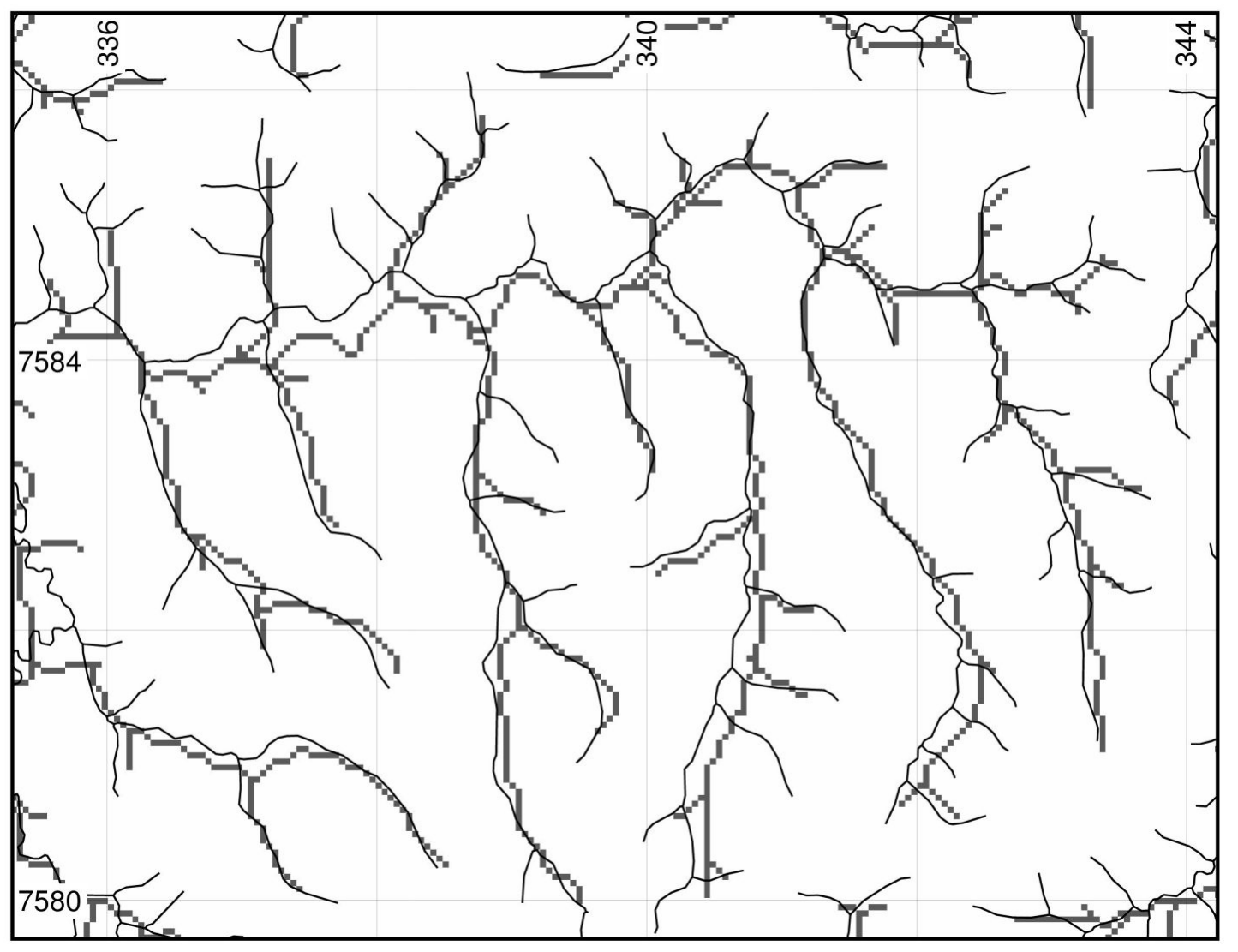

Figure 6. Vector drainages of 1:50 000 topographic map overlaid on DEM-derived drainages. 

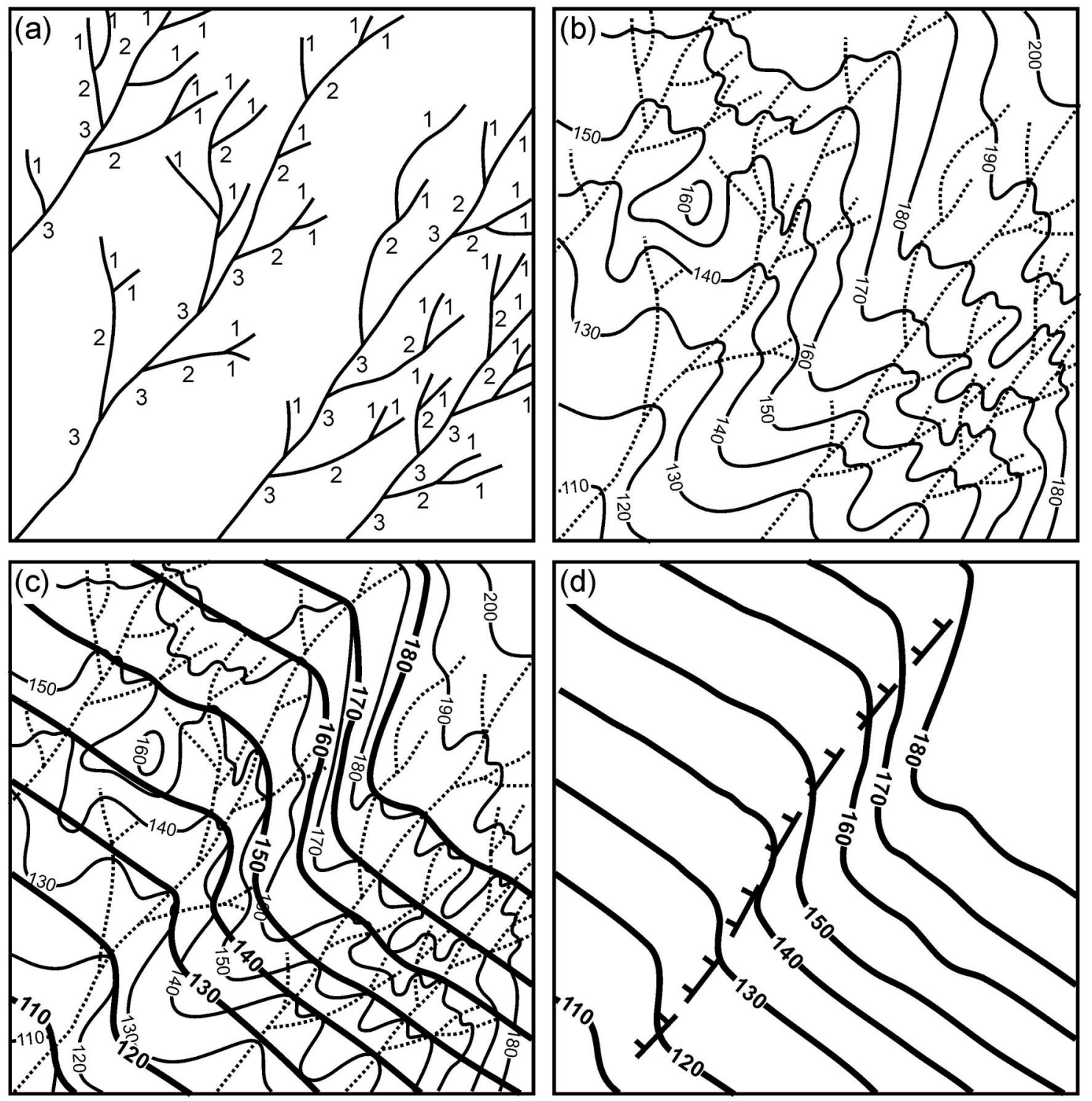

Figure 7. Development of isobase map. (a) Definition of stream orders. (b) Overlay of drainage network and contours. (c) Isobase lines derived from $2^{\text {nd }}$ and $3^{\text {rd }}$ order streams. (d) Fault traced according to deviations of isobase lines. Reprinted from Golts and Rosenthal, Geomorphology, 7:305-315, Copyright 1993, with permission from Elsevier. 


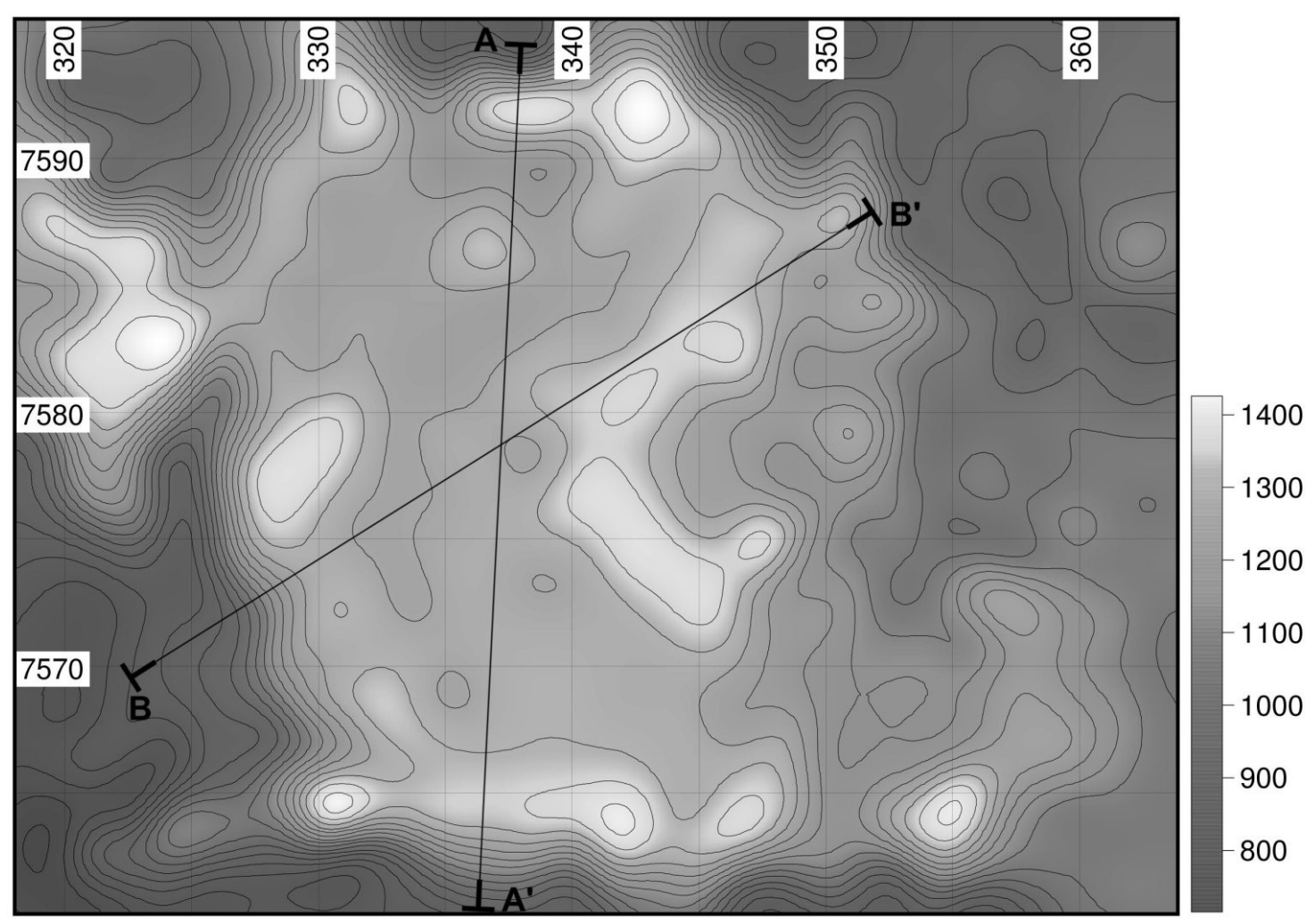

Figure 8. Isobase map. 


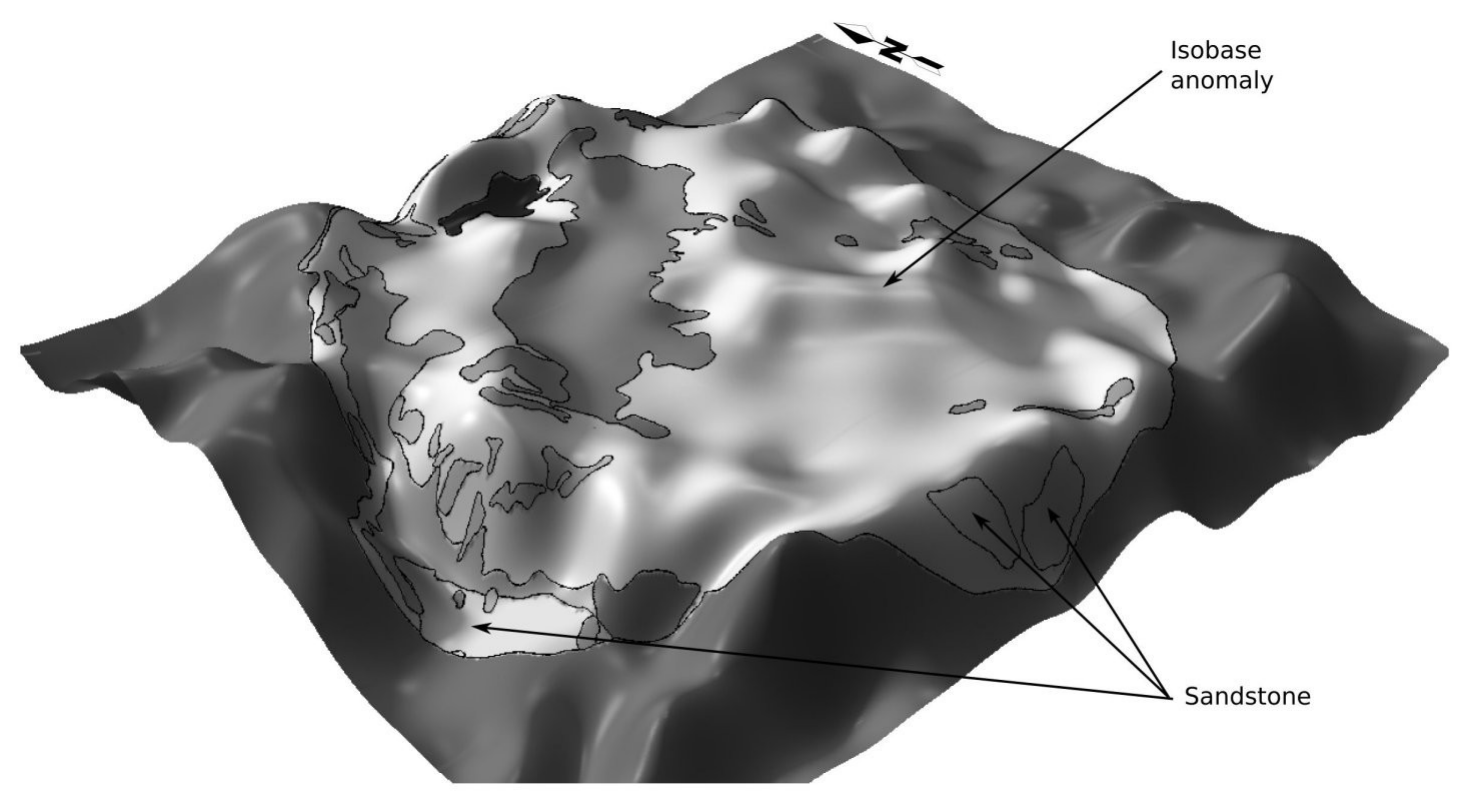

Figure 9. 3D-view of geology draped over isobase surface, viwed from southwest to northeast. Vertical exageration of 10x. 

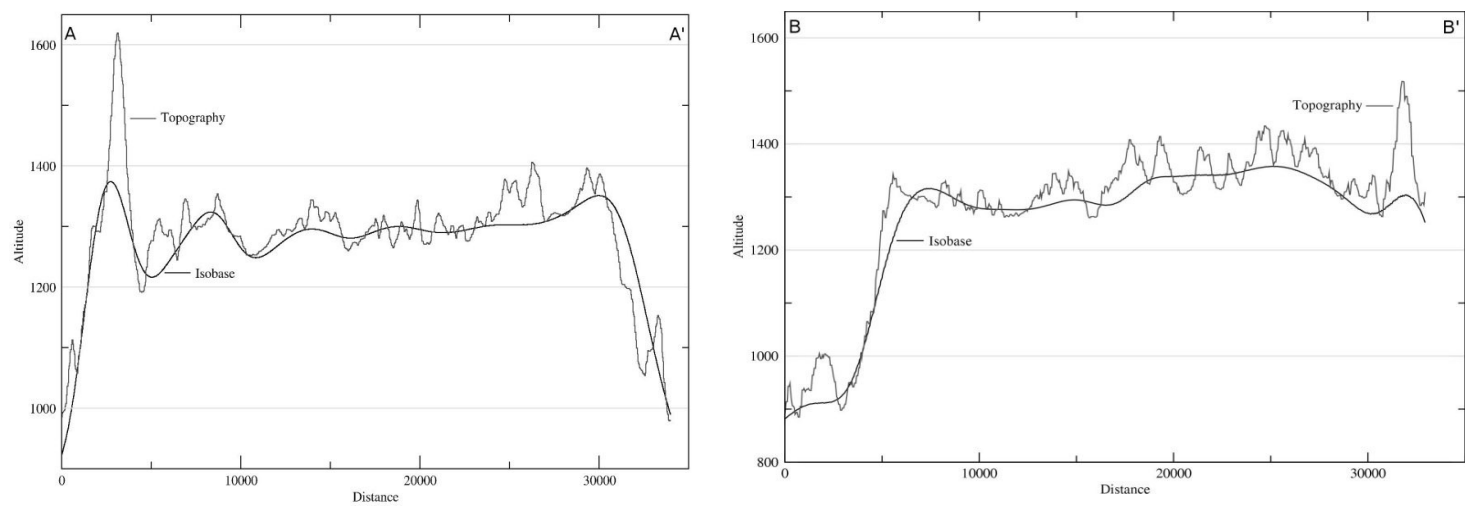

Figure 10. Morphological profiles across the massif showing topography and isobase relations. a)N-S profile. b)SW-NE profile. 